\title{
CAN RETURN MIGRATION REVITALISE LATVIA'S REGIONS? FACILITATORS AND BARRIERS TO HUMAN CAPITAL GAINS
}

\author{
Inta Mieriņa \\ University of Latvia, Latvia \\ Baiba Bela \\ University of Latvia, Latvia
}

\begin{abstract}
Migration researchers from East-Central Europe most often focus on the impact of 'brain drain' which is characterised by the loss of human capital from emigration. In this paper focus is placed on the assumption that migrants living abroad gain valuable experiences and education opportunities, that lead to personal growth, facilitate entrepreneurship and psychological resilience, amongst other important skills. This experience may be used for the revitalisation of the less-developed regions the migrants return to. To explore what facilitates or inhibits the fulfil potential of 'brain circulation' or gain, we use data from two large-scale surveys of return migrants in Latvia, in-depth interviews, media analysis, regional workshops and secondary data. We find that return migrants often choose to return to the capital city and not their original point of departure. While towns and villages offer some advantages such as little competition, easier adaptation and high neighbourhood quality, reliance on personal contacts distorts the efficiency of job placement and there are fewer work opportunities in one's acquired profession. The skills are waisted and employers remain unappreciative of knowledge gained abroad in towns and villages more than in Riga.
\end{abstract}

Keywords: return migration, brain circulation, brain gain, knowledge, education.

\section{Introduction}

During the last decade migration researchers have increasingly focused on the human capital costs of emigration on the sending countries such as those in East and Central Europe. This is most pronounced when people with higher education are over-represented among emigrants or when young people acquire higher education abroad and decide to stay there (Atoyan et al., 2016; Hazans, 2015a). The return of educated professionals is widely recognised as an important contributory resource for the economic innovation and development in the country of origin (Suciu \& Florea, 2017). Thus, in order for international mobility to have a positive effect on sending countries such as Latvia, it is crucial to achieve 
substantial rates of return migration or, alternatively, of highly qualified immigration. The regional inequalities in development in Latvia are significant and continue to grow (Rasnača \& Bela, 2015; VARAM, 2013; VRAA, 2020). The gap between the capital Riga with its surrounding municipalities (Pierīga) and the rest of the territory, especially Latgale, continues to widen in terms of income, job opportunities, production volumes, GDP, investments etc (Rutkovska, 2018; VRAA, 2020). A similar situation is observed in relation to human capital - it is higher in Riga and Pierīga and lower in all other regions (Šķiṇkis, Vilka, Cimdiņš, \& Ušča, 2015).

We posit that return migration has a potential to revitalise and strengthen economic development and competitiveness of Latvia's regions. Because return migrant may bring enhanced human capital in the form of professional competency and transferrable skills that were acquired abroad through education. The aim of this paper is to provide a more detailed understanding of the transfer of human capital acquired abroad by return migrants. To achieve this, factors that hinder or facilitate migrants' return to smaller localities and utilisation of their skills, are explored. The research questions we ask are: i) are migrants less likely to return to towns and villages than the capital city or other large cities? ii) what advantages attract returning migrants to smaller towns and localities in regions and iii) what factors, including those related to job-search and employers' attitudes, can hinder the utilisation of return migrants' skills in regions. Research implements a mixed-method model with the use of both quantitative and qualitative data analysis, alongside analysis of secondary statistical data.

\section{The Importance of Migration for Regional Development}

On the one hand, the new economics theories and the neoclassical growth models elaborate various mechanisms on how international labour mobility can accelerate convergence between countries, boost employee wages and boost national development (McCann, 2013; Barro \& Sala-i-Martin, 2004). On the other hand, the classical rational choice theories or Wallerstein's (1990) world systems theory see international migration as inevitably draining the resources of the poorer countries and turn them into permanently dependent peripheries of the global economy. Brain drain - the emigration of skilled people reduces development opportunities in poor countries (because it reduces social capital) and deepens the inequality as poor countries continue to subsidise the rich countries. The negative effect of brain drain is observed in reduced productivity of stayers (Docquier, Ozden \& Peri, 2014) and in lowered stock of human capital (Haque \& Kim 1995; Atoyan et al., 2016; Hazans 2015a). We argue that this may be offset by real wage convergence and expected positive productivity effects from return migration. 
Migration balance in Latvia is still negative, and emigration remains the main source of population decline (Kaša \& Mierina, 2019). The Ministry of Economics (2019) points out that it is crucial to achieve a positive migration balance in the near future, as has already been done by the neighbouring Estonia, in order to ensure economic growth and meet the increasing demand for labour. Sustainable Development Strategy of Latvia until 2030 also indicates that the demographic and labour market changes require targeted return migration or controlled labour immigration policies (Saeima of the Republic of Latvia, 2010). Both policy-makers and employers report preference for return migration instead of immigration (Mierina, Ose, Kaprāns, \& Lāce, 2017). Unfortunately, current return migration policies have not successfully achieved brain drain compensation in Latvia, as less than $40 \%$ return in within 10 years after emigrating (Hazans, 2015b, 2020).

When analysing regional trends in migration flows in 2012-2013, Hazans (2015b) concluded that during these two years return migration flows in Riga and the countryside were less than $40 \%$ of the emigration flows, whereas in Daugavpils, Liepāja and Jelgava it was more than $50 \%$. Return migration rates were the lowest, compared to emigration, in Riga and Zemgale, but the highest in Pierīga (Labour Force Survey [LFS] data). Simultaneously, domestic migration should also be taken into account. Many emigrants, whose last place of residence in Latvia was in a city, were born and raised in the countryside. This means that the full (direct and indirect) effect of emigration on rural depopulation may be much greater than can be judged from the LFS data. Because in LFS the emigrants' last place of residence in Latvia is used as the point of reference. With the exception of Riga and Pierīga, all parts of Latvia experience a population loss not only as a result of international but also domestic migration. If current tendencies continue, the number of inhabitants in most regions is expected to decrease by almost $1 / 3$ by 2030 (Krēsliņš, Miglavs, \& Spuriņš, 2015). An another reason for scepticism that return migration may compensate for the brain drain, is that across all time periods there are fewer university graduates among return migrants than among those of similar age in Latvia (Hazans, 2015a).

Though a formal education background may not be exclusively needed for the brain drain compensation. As research on return migration in Italy and Spain indicates that soft skills, informal and tacit competences acquired abroad are considered to be as important as formal qualifications (Staniscia et al., 2019). Research by Kurekova and Žilinčíková indicates, that foreign work experience is an asset for (re)integration into the home labour market (2018). Research from Bulgaria suggests, that return migrants' foreign education and experience encourages them to pursue activities which are meaningful both for civil society development and for innovative (social) entrepreneurship (Glorius, 2019). 
To counter depopulation that deepens existing regional development disparities in Latvia, increasing positive effects of return migration is of great importance. Therefore, the study examines whether and how return migrants' human capital gains - education, professional competences and transferable skills acquired abroad, helps them re-integrate into the home labour market and contribute to regional development. The study also investigates whether the same trends can be observed as demonstrated by research above.

\section{Methodology}

The analysis combines quantitative and qualitative data, alongside media analysis and analysis of secondary statistical data. The quantitative data are drawn from two large scale Web surveys conducted by the researchers at the University of Latvia: a survey of return migrants: "Returning to Latvia" in 2016 (3088 respondents, Hazans, 2016) and "Well-being and integration in the context of liquid migration” in 2019 (1460 respondents, Korol̦eva, 2020). Respondents were recruited online through a variety of recruitment channels such as a job-search portal CV-Online and social media. The data were statistically weighted so that the ethnicity, education, gender and age distribution of respondents at the time of return would match as closely as possible the reference group of return migrants (information obtained from the latest LFS, see Hazans, 2016). In this paper we particularly focus on questions concerning the perceived value of knowledge acquired abroad, job-search strategies, application of the acquired skills, adaptation to difficulties and satisfaction with various aspects of life (precise wording indicated in the figures). Return migration statistics is drawn from the Central Statistical Bureau of Latvia. The data were analysed in IBM SPSS 22 using simple univariate and bivariate statistics, dispersion analysis (ANOVA), Ttests and chi-square statistics to test for the significance of differences between groups.

The qualitative data was obtained from several key sources. 15 biographical interviews with transnationals, Latvian students abroad and return migrants (conducted 2019) was obtained from the National Research Programme «Towards sustainable development and inclusive society in Latvia: response to demographic and migration challenges». Data from four regional workshops (2019) was used. 28 interviews with return migrants and their spouses (40 people) were obtained from the IR weekly magazine thematic series "Back Home" (published in 2018 and 2019). Thematic analysis was used to gain an in-depth understanding on how skills, experiences, formal and informal education that is gained abroad is transferred and applied in Latvia. The analysis sheds light on the facilitators and barriers for return migration and human gains. Qualitative and 
SOCIETY. INTEGRATION. EDUCATION

Proceedings of the International Scientific Conference. Volume I, May $28^{\text {th }}-29^{\text {th }}$, 2021. 142-159

quantitative data were integrated during analysis. Qualitative data are used to illuminate and expand some findings from quantitative analysis.

\section{Research Results}

\section{Return migration in numbers}

The Central statistical bureau [CSB] of Latvia data shows that most emigration-caused depopulation occurred in small towns, villages and the countryside. For example, in 2015-2019 the ration of immigration to emigration was $79 \%$ in Riga, $47 \%$ in the other eight largest cities and $42 \%$ in towns, villages, and the countryside. This means that during these five years the number of people who emigrated from the smaller towns and the countryside was double to those who immigrated (37.3 thousand vs.15.5 thousand). While there are no specific data about regions, CSB data shows that in the last two years almost half (45\%) of all immigrants were return migrants (CSB 2019). We may only assume that outside the larger cities this percentage is even higher.

The number of return migrants that CSB defines as people who have returned after spending at least 12 months abroad, has fluctuated at around 5000 each year since 2015. However, as Hazans (2020) notes, the estimates for return migration and the net number of return migrants in the country depend on the definition that is used. Mainly, on how long they had to live or work abroad and for how long they are considered return migrants after returning (ibid.). For example, using LFS and EU-SILC data, Hazans (2020) calculates that during 2013-2018, 10,00011,000 people who worked abroad in the previous year returned to Latvia every year, i.e., about twice as many as the CSB estimate. In total, according to Hazan's (2020) calculations from the CSB data, at the beginning of 2019, 12,670 adult (aged 15 years old or older) return migrants lived in Latvia who had returned to Latvia in 2015-2018 before spending at least 1 year abroad. Based on LFS and EU-SILC data, between 2008-2018, 53,000 unique persons returned to Latvia with work experience gained abroad during the previous 15 months, and 117,000 unique persons with work experience gained abroad during the previous 4 years (Hazans, 2020).

The distribution of return migrants by regions during 2015-2019 mostly correspond to the distribution of the population (average total number), but with a slightly smaller share of return migrants in Latgale and a larger share - in Pierīga (Table 1). This means that return migrants boost the number of inhabitants in Pierīga, yet in Latgale return migration is not able to compensate for the loss of population. 
Table 1 Return Migration Statistics (\%)

\begin{tabular}{|c|c|c|c|c|c|c|c|c|c|c|}
\hline & \multicolumn{7}{|c|}{ Number of return migrants } & \multirow{2}{*}{\begin{tabular}{|c} 
Percentage of \\
inhabitants of \\
Latvia \\
residing in \\
particular \\
regions \\
\\
\\
2015- 2019 \\
$(\%)$
\end{tabular}} & \multicolumn{2}{|c|}{ Net migration } \\
\hline & 2015 & 2016 & 2017 & 2018 & 2019 & $\begin{array}{l}2015- \\
2019\end{array}$ & $\begin{array}{c}2015- \\
2019 \\
(\%)\end{array}$ & & Net & $\begin{array}{c}\text { As \% of } \\
\text { inhabitants } \\
\text { during } \\
\text { 2015-2019 }\end{array}$ \\
\hline Total & 5617 & 5409 & 5455 & 4852 & 5114 & 26447 & 100 & 100 & -38942 & -0.4 \\
\hline Riga region & 1929 & 1813 & 1897 & 1499 & 1529 & 8667 & 32.8 & 32.8 & -4120 & -0.1 \\
\hline $\begin{array}{c}\text { Pierīgas } \\
\text { region }\end{array}$ & 824 & 840 & 845 & 865 & 874 & 4248 & 18.9 & 16.1 & 6865 & 0.4 \\
\hline $\begin{array}{l}\text { Vidzemes } \\
\text { region }\end{array}$ & 534 & 525 & 534 & 509 & 566 & 2668 & 9.8 & 10.1 & -9595 & -1.0 \\
\hline $\begin{array}{l}\text { Kurzemes } \\
\text { region }\end{array}$ & 734 & 701 & 713 & 673 & 708 & 3529 & 12.6 & 13.3 & -10900 & -0.9 \\
\hline $\begin{array}{l}\text { Zemgales } \\
\text { region }\end{array}$ & 724 & 658 & 636 & 591 & 640 & 3249 & 12.1 & 12.3 & -8576 & -0.7 \\
\hline $\begin{array}{l}\text { Latgales } \\
\text { region }\end{array}$ & 872 & 872 & 830 & 715 & 797 & 4086 & 1.8 & 15.4 & -12616 & -0.9 \\
\hline
\end{tabular}

Source: CSB (2019), data provided at request of the authors

Interestingly, the number of people returning to Latgale and Riga in the last 5 years has decreased, while the number of those returning to Pierīga has slightly increased. Overall, the net migration (i.e., the difference between immigration and emigration) during 2015-2019 is relative to the number of inhabitants, Kurzeme, Vidzeme, and Latgale have lost the most inhabitants to migration (almost 1\% during the 5 years' time). The net migration in Riga is close to zero, whereas Pierīga has been the beneficiary of migration. Though the net migration rates provided by CSB include both internal and external migration.

According to CSB data, most return migrants $15+$ years of age who resided in Latvia at the beginning of 2019 and had returned to Latvia during 2015-2018 are young - up to 44 years of age (Table 2). Just 17\% are 55 years or older. This attests to their economic potential. Particularly few returning to Latgale, Zemgale and Vidzeme are 55 or older. However, only 23\% of return migrants 15 or older who resided in Latvia at the beginning of 2019 and had returned in 2015-2018 had higher education - a lower number than among emigrants or diaspora (CSB 2019; Atoyan et al., 2015; Hazans, 2015b). 
SOCIETY. INTEGRATION. EDUCATION

Proceedings of the International Scientific Conference. Volume I, May $28^{\text {th }}-29^{\text {th }}$, 2021. 142-159

Table 2 Age Structure of Return Migrants Residing in Latvia in 2019 Who Returned during 2015-2018 (\%)

\begin{tabular}{|c|c|c|c|c|c|c|}
\hline & $15-24$ & $25-34$ & $35-44$ & $45-54$ & $55-64$ & $65+$ \\
\hline Total & 6 & 38 & 25 & 14 & 11 & 6 \\
\hline Riga region & 6 & 34 & 25 & 16 & 12 & 7 \\
\hline Pierīgas region & 6 & 37 & 26 & 12 & 11 & 7 \\
\hline Vidzemes region & 5 & 42 & 24 & 13 & 10 & 3 \\
\hline Kurzemes region & 7 & 40 & 22 & 13 & 11 & 5 \\
\hline Zemgales region & 7 & 40 & 25 & 14 & 9 & 4 \\
\hline Latgales region & 3 & 43 & 26 & 13 & 10 & 3 \\
\hline
\end{tabular}

Source: CSB (2019), data provided at request of the authors. Row percentages.

\section{Job placement}

In the survey return migrants were asked, how did they find their job after returning. Chi-square tests show that there are significant differences between different types of localities (Sig.<0.001). While advertisements are the most common route for finding work in Riga, elsewhere social contacts play a bigger role: people often find a job with the help of family or friends (46-47\%), some return to their previous employer or just create a workplace themselves (Table 3). Reliance on personal contacts does not guarantee a job that is best suited for their level of skills and competences, thus, there is a higher risk that outside Riga return migrants' skills might be wasted. Interestingly, the data provides no clear indication that such strategies of job-search are a result of being unable to find a job using other methods: there are no statistically significant differences in how long it took for the return migrants to find a job in Riga, other large cities or towns and villages (Sig.>0.05). Thus, this could rather be explained by cultural traits or a lack of belief in other possibilities to find a job (not trying).

Table 3 How Return Migrants Found Job after Returning (\%)

\begin{tabular}{|l|r|r|r|}
\hline & \multicolumn{1}{|c|}{ Riga } & \multicolumn{1}{|c|}{$\begin{array}{c}\text { Other } \\
\text { large cities }\end{array}$} & $\begin{array}{c}\text { Towns and } \\
\text { villages, } \\
\text { countryside }\end{array}$ \\
\hline Referring to an advertisement & 41.8 & 27.2 & 27.5 \\
\hline With the help of family and friends & 37.2 & 46.3 & 46.9 \\
\hline $\begin{array}{l}\text { By placing an advertisement or CV on one of the } \\
\text { Internet portals }\end{array}$ & 9.7 & 7.7 & 6.3 \\
\hline Created the workplace myself & 7.8 & 12.3 & 9.4 \\
\hline Returned to my previous employer & 7.4 & 7.7 & 10.3 \\
\hline Using the services of public employment services & 1.0 & 3.1 & 5.2 \\
\hline Other & 4.6 & 4.8 & 5.4 \\
\hline Difficult to say/ Don't remember & 0.4 & 0.0 & 1.2 \\
\hline
\end{tabular}

Source: "Returning to Latvia” (2016) 
The brain wasting is confirmed by the respondents' further answers to the question about the use of skills acquired abroad in their current job (Fig.1). In Riga just 22\% do not use or practically do not use skills acquired abroad, whereas in towns and villages this proportion reaches $42 \%$.

We also asked if the respondent works in a profession that fits their qualification. 23\% in Riga, 26\% in other large cities and 33\% in towns, villages and the countryside work a simpler job, attesting to down-skilling after return. 10$11 \%$ in Riga and other large cities work a job that exceeds their formal qualifications, which indirectly indicates the appreciation for their skills among employers. Yet just 5\% have managed to secure such a job in towns, villages, and countryside.

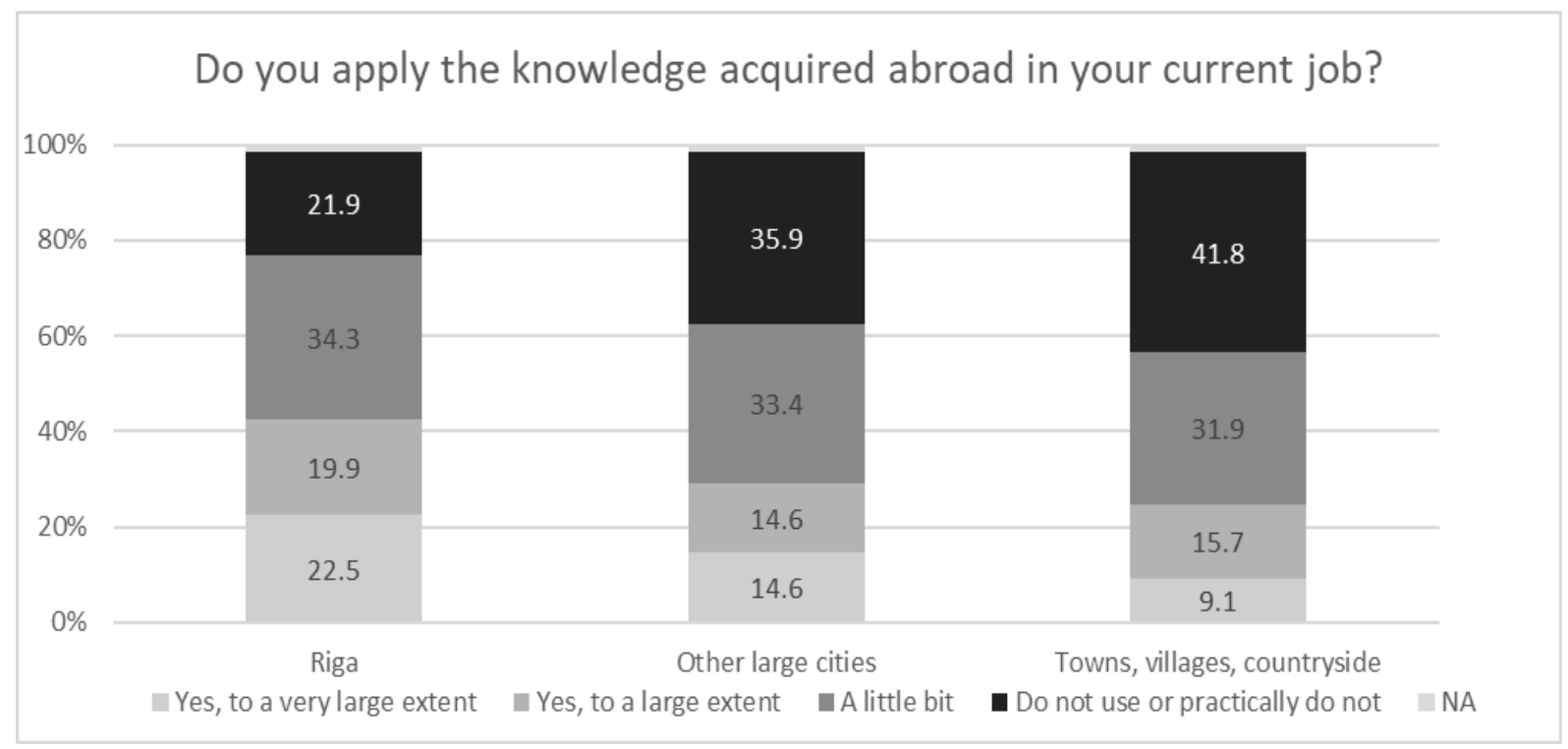

Figure 1 Application of Skills Acquired Abroad in Current Job (\%)

Source: "Returning to Latvia” (2016)

Additional confirmation of smaller town, village and the countryside employer insufficient use of return migrant skills is visible in further questions. The share of return migrants who believe that employers 'do not value' or 'rather do not value' experience and skills acquired abroad is just 35\% in Riga, compared to more than half (51-52\%) in other cities, towns, villages or countryside (Fig.2). 


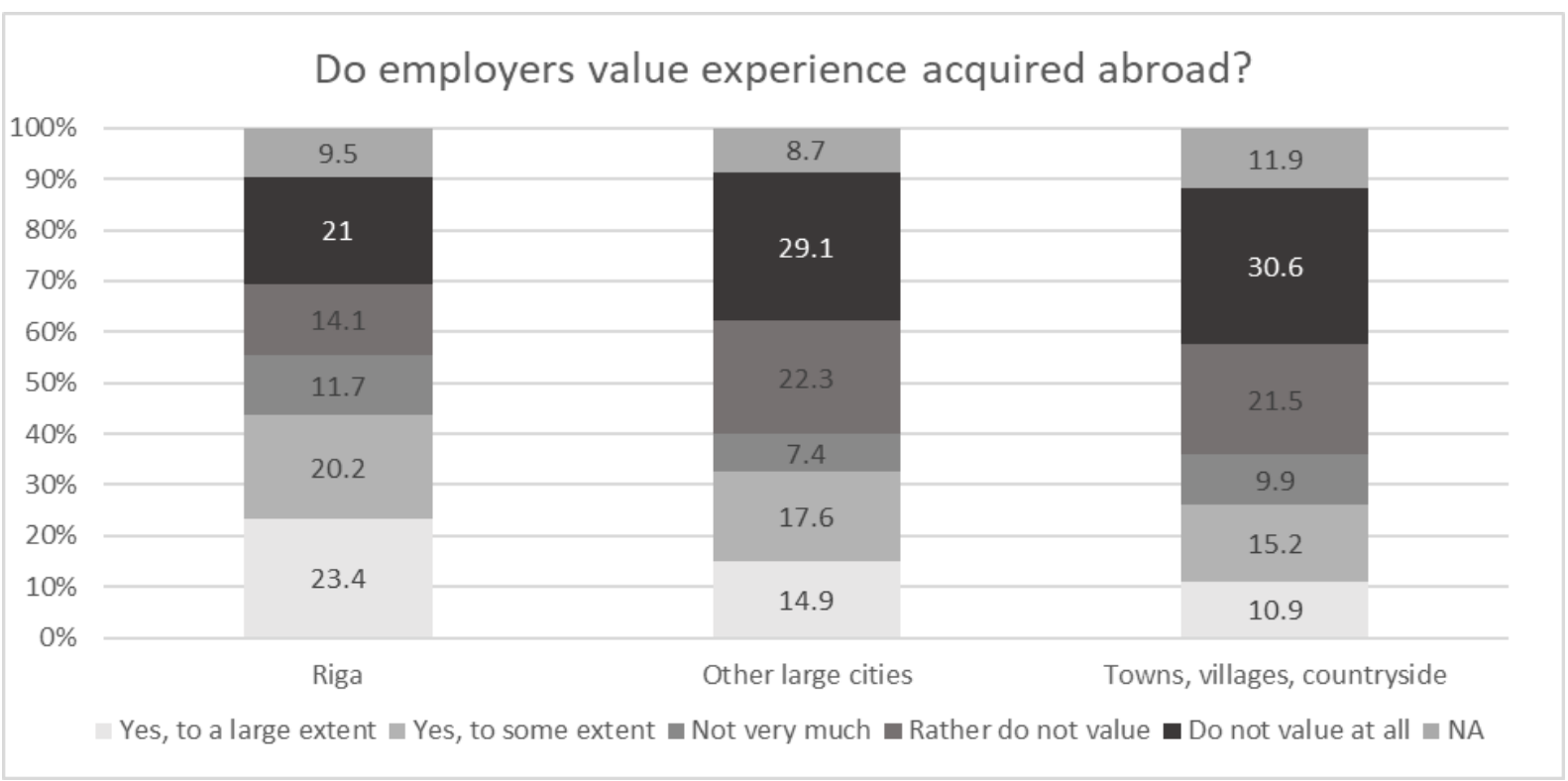

Figure 2 To What Extent Employers Value Skills Acquired Abroad in Current Job (\%) Source: "Returning to Latvia" (2016)

Simultaneously, the data from the regional workshops indicate a lack of human resources. Particularly all regions display a lack of skilled specialists in many areas (in education, health care, IT, engineering). The brain-wasting, downskilling of return migrants and the insufficient use of return migrants' skills may be explained by a mismatch between the return-migrant qualifications and the needs of the regional labour market, more narrow employment opportunities, or irresolvable workplace cultural differences. Another factor may be that those who have worked abroad more critically evaluate employer attitudes and tend to have higher demands for work conditions and wages as they realize the value of their work (Mierina, 2015). Thus, for some employers in the regions the extra experience acquired abroad makes a potential employee too demanding or too expensive, even though the skills would fit the job perfectly. This can result in scepticism towards returnees and in downplaying the value of their experience. In addition, the qualitative data suggests that people who are oriented towards work in a multinational collective and value opportunities provided by globalization prefer employment in international companies. Those for whom opportunities and choices (employment, services, culture, sports etc) offered by the capital city are important, are more inclined to stay in Riga. Towns and rural areas are attractive to families with children who prioritise quality of life (facilitating factors for this are discussed in detail in the next section), may adapt flexibly to the existing labour market, see opportunities to develop their own business or can continue their work remotely for employers or customers outside Latvia. The interviews also confirm a perception that there is no demand or limited opportunities for 
niche qualifications in Latvia (e.g. gender studies, urban studies, human rights). In contrast to quantitative data, qualitive data shows more successful transfer of knowledge, skills, acquired formal and non-formal education.

\section{Skills, formal and non-formal education acquired abroad}

The knowledge economy of the 21st century can develop only if there is sufficiently high human capital - skilled and educated people who can create innovative, high quality products and services. According to the results of the 2019 survey, 41\% of return migrants think that they are irreplaceable or difficultto-replace employees in their current job. The skills that make them so valuable are, according to our respondents, their ability to perform certain tasks better than others (61\%), broad professional competence, experience (59\%), ability to handle non-standard situations (52\%), ability to think differently, to notice different solutions (49\%), as well as language skills (44\%). Thus, the return migrants themselves consider as valuable not just the professional skills they have acquired while working abroad, but also competences they have learnt outside of workplace, in a non-formal way, by having to adapt to unfamiliar circumstances in terms of language, culture, institutions, etc.

The qualitative data suggest that it is not just particular skills, but also attitudes and mindsets, that create life transformative consequences. Attitudes identified in the media interview analysis are - not to be afraid, take initiative, try new things, do not give up, openness to diversity, tolerance, a positive mindset. Skills mentioned are - a friendly communication style, punctuality and precision, a quick pace of work, strong adaptation skills, ability to talk freely about all topics. Professional qualifications were also mentioned, both university education and formal and non-formal professional training. Some have acquired professional training in the hospitality sector, which allowed them to start their own businesses in Latvia (mainly outside Riga). Few learned the language of the host country at a level that allows them to teach it in Latvia after their return. Indeed, experience gained abroad is an asset that motivates many return migrants to start their own businesses. Many are engaging in the activities, which are meaningful for civil society or local communities.

Regarding the place of residence, where skills and knowledge are applied in Latvia, interview data and media interview analysis correspond to the same trend as surveys show - return migrants with higher education are tended to stay in Riga (even if they are born in rural municipalities or smaller towns), with very few exceptions. But even so towns and villages are benefiting from return migrants' human capital and transfer of attitudes, skills and knowledge. Some are starting university studies because while abroad they have seen the importance of higher education and found their field of interest. 


\section{Barriers and facilitators to returning to regions}

In terms of barriers for adaptation after the return to Latvia, almost half (45\%) of respondents who returned to towns, villages or the countryside characterise it as being very easy or easy, compared to approximately $37 \%$ in Riga and other large cities, thus, their adapting was somewhat easier (Fig.3).

However, the respondents also highlighted some barriers to integration after their return. Those working in Riga more often than others mention language issues among difficulties they faced - mainly due to a common requirement in the business sector to be fluent in both Latvian and Russian. Return migrants in other cities were more concerned than others about economic issues: difficulty finding employment and the calculation and transfer of pensions and benefits. This aligns with the CSB data that shows that while income levels are lowest in villages and the countryside, unemployment rates there are lower than in large cities (Hazans, 2015b).

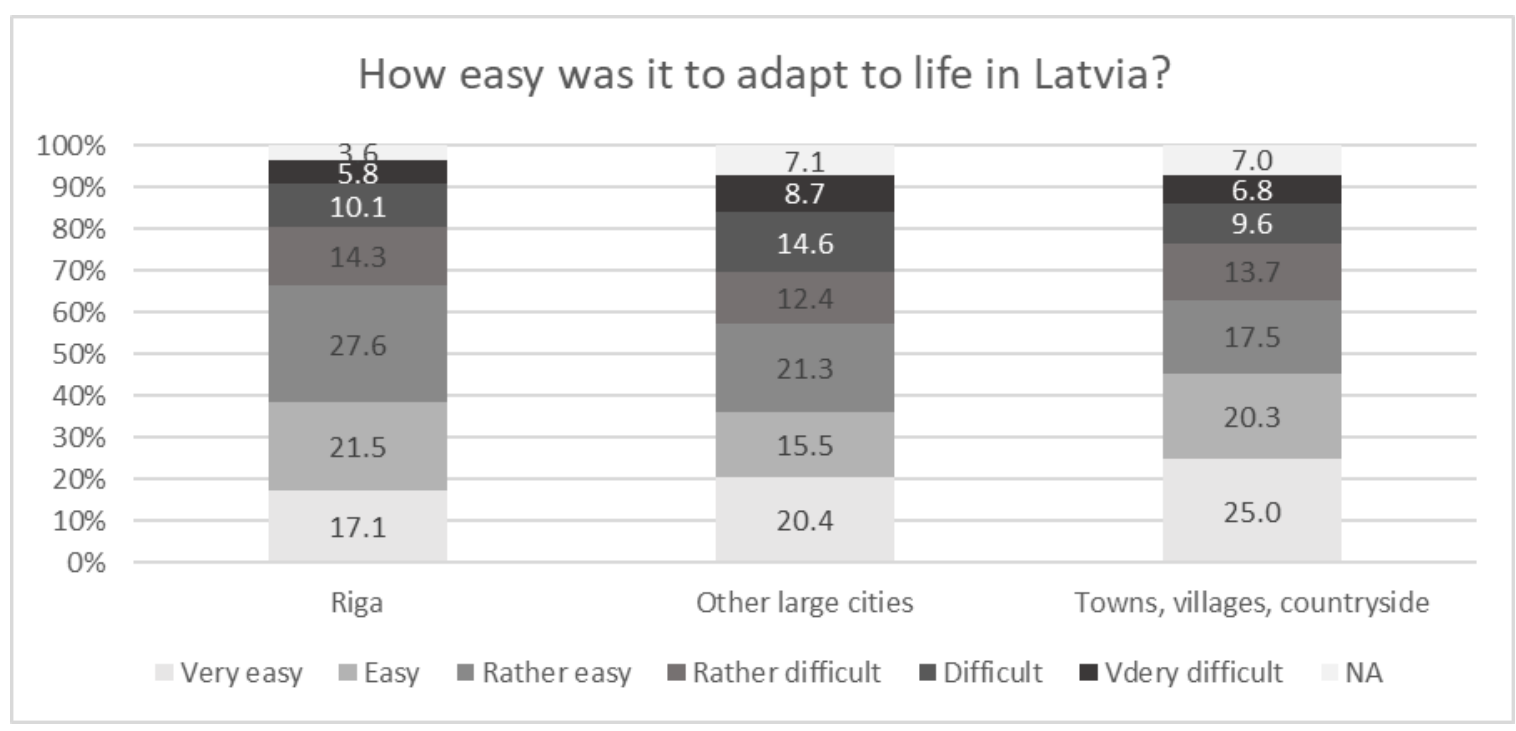

Figure 3 Difficulty of Adapting to Life in Latvia (\%)

Source: "Returning to Latvia" (2016)

Finally, those who returned to work in towns, villages or the countryside less often report difficulties integrating into the local society due to a different mentality, and had fewer uncertainties about the health care system compared to those in Riga (Table 4). The later could be because fewer elderly people return to the countryside and potentially due to tighter and more personal relations between doctors and patients in small towns and villages.

The survey also asked respondents what would have helped them to better integrate after their return. Return migrants living and working in different types of settlements provide the same answers (Sig, $>0.05$ ): employment opportunities with adequate pay would help the most (64\%), followed by business and 
municipal support to find a place to live (27\%). Interestingly, return migrants in small towns, villages and countryside would find information about employment opportunities less useful (27\%) than those in Riga (36\%). This points to the fact that the lack of information about jobs is not seen as the main problem, but rather the key problem is the lack of adequately paid jobs in general.

Table 4 What Difficulties Return Migrants Faced after Returning (\%)

\begin{tabular}{|c|c|c|c|}
\hline & Riga & $\begin{array}{l}\text { Other } \\
\text { large } \\
\text { cities }\end{array}$ & $\begin{array}{c}\text { Towns } \\
\text { and } \\
\text { villages }\end{array}$ \\
\hline Language difficulties & 15.2 & 6.7 & 6.9 \\
\hline Difficulty finding a place for a child in kindergarten & 7.9 & 7.5 & 7.4 \\
\hline Difficulty finding a place for a child in school & 2.3 & 1.5 & 0.8 \\
\hline Dissatisfaction with the school environment, attitude & 7.2 & 6.7 & 4.1 \\
\hline $\begin{array}{l}\text { Difficulties in getting a diploma or a qualification } \\
\text { recognized in Latvia }\end{array}$ & 4.1 & 3.3 & 2.1 \\
\hline Difficulty for a spouse to find a job & 12.6 & 18.2 & 14.2 \\
\hline Uncertainty about taxes & 28.3 & 30.6 & 29.5 \\
\hline $\begin{array}{l}\text { Difficulties with benefits and pension calculation or } \\
\text { coordination }\end{array}$ & 8.5 & 15.6 & 7.5 \\
\hline Difficulty finding a job & 29.6 & 38.5 & 28.2 \\
\hline Difficulty finding a place to live & 16.9 & 22.6 & 18.0 \\
\hline Uncertainties about the health care system & 25.4 & 22.4 & 17.6 \\
\hline $\begin{array}{l}\text { Difficulties in integrating into society (different } \\
\text { people's mentality) }\end{array}$ & 27.5 & 27.5 & 20.5 \\
\hline Difficulty getting used to a different work culture & 33.5 & 34.0 & 29.1 \\
\hline Other difficulties & 12.6 & 6.7 & 13.4 \\
\hline There were no difficulties & 16.7 & 18.3 & 18.4 \\
\hline
\end{tabular}

Source: "Returning to Latvia" (2016). The percentages show how many respondents in the particular group mentioned certain difficulties. More than one answer was possible, thus, they can sum up to more than $100 \%$.

Data from the regional workshops confirm that low remuneration is one of the key factors why people leave towns, villages and the countryside and what prevents recruitment of skilled labour and highly qualified specialists. Also, difficulty to find affordable quality housing is a lingering factor. Despite depopulation, the housing stock is limited, out of date and inadequate to contemporary requirements. Furthermore, banks do not provide mortgage for housing acquisition or construction outside prospective city centres. On the other hand, successful companies offer competitive salaries to qualified professionals, but the limited opportunities in small towns and the countryside (limited access 
to and choice of services, limited cultural and entertainment opportunities) discourage young people from moving to a place that is far from the capital.

Those working in Riga are significantly more satisfied with work conditions, remuneration and are happier with their life in general than those who work outside of Riga in towns, villages, and the countryside (Sig.<0.05). Income-wise, too, those working in towns, villages or countryside, or even large cities often ( $41 \%$ and $37 \%$, respectively) find it difficult to make ends meet - compared to just $25 \%$ of return migrants working in Riga (Table 5).

Table 5 Satisfaction with Various Aspects of Life (0-10)

\begin{tabular}{|l|r|r|r|}
\hline & \multicolumn{1}{|c|}{ Riga } & \multicolumn{1}{|c|}{$\begin{array}{c}\text { Other } \\
\text { large } \\
\text { cities }\end{array}$} & \multicolumn{1}{|c|}{$\begin{array}{c}\text { Towns, } \\
\text { villages, } \\
\text { countryside }\end{array}$} \\
\hline Job & 6.8 & 6.5 & 6.5 \\
\hline Work conditions & 7.1 & 6.5 & 6.2 \\
\hline Remuneration & 5.5 & 4.9 & 4.7 \\
\hline Family life & 7.2 & 7.3 & 7.4 \\
\hline Relationships with people outside family & 7.1 & 7.4 & 7.3 \\
\hline Home/ dwelling & 6.9 & 7.4 & 6.9 \\
\hline Current standard of living & 5.8 & 5 & 5.3 \\
\hline Life in general & 7.1 & 7 & 6.7 \\
\hline
\end{tabular}

Source: "Well-being and integration in the context of liquid migration" (2019)

Overall, those who returned to Riga, mention diverse reasons for why they decided to return. More than those who returned to other types of settlements they mention social reasons (missing their family and friends, the fact that their loved one lives in Latvia or decided to return), as well as economic reasons (dissatisfaction with some aspects of life abroad or an attractive job offer in Latvia) which indicates that Riga is probably seen as better able to offer them better conditions. Those who returned and work in Riga, also more often returned due to finishing their studies abroad. The fact that Riga is better able to attract the young specialists who have acquired education abroad is worrying. Those who returned to other cities, towns or villages in Latvia, most often did so mainly due to emotional reasons: missing family and friends, longing for Latvia, other family or personal circumstances or desire for children to live and study in Latvia. Interviews also show this trend. It is people without higher education that return to the towns and the countryside more often. They see their way of life closer to nature, family and their roots. A multicultural city environment and a higher salary are not priority attractors.

When asked about their plans for the future, both surveys, and different measures point to the same - return migrants working in small towns, villages or 
the countryside are much less willing to emigrate again: $40 \%$ say that after five years they will definitely still live in Latvia (compared to 21\% in Riga an 28\% other large cities). Simultaneously, the former group is also more unsure about whether in five years' time they will still live in Latvia (19\% compared to $13 \%$ in cities). This means that their plans are dependent on opportunities presented. These results align with "The emigrant communities of Latvia" survey results that found that those from the small towns, villages and the countryside were most likely to express willingness to return to Latvia (approximately 20\% had plans to return), especially those from Vidzeme or Pierīga. This seems indicative of a stronger attachment among those from smaller settlements to their place of origin and community. Indeed, survey data shows that in rural areas, as well as in Riga, fewer individuals do not feel attached to Latvia compared to other larger cities or towns (Hazans, 2015).

The qualitative data also confirms the importance of place attachment and sense of belonging. Here qualitative analysis provides a deeper understanding of other attractive factors for choosing a rural life, identified in regional workshops and media interviews. Firstly, families with children positively review the quality of life in towns, villages and the countryside in three key aspects. Firstly, the life environment is perceived as green, quiet, peaceful, close to nature, with clean air and food, with safe opportunites for children to go to and from school and extracurricular activities and no time is spent in traffic jams. Secondly, rural life offers a peaceful rhythm of life. Lastly, a rural life gives a chance to practice ones own life philosophy, sustainable lifestyle or to live in accordance to Latvian traditional values and ways of life. For parents of minors, a significant factor is availability of kindergartens, as well as a broad, affordable, and high-quality offer of extracurricular activities for pupils.

An additional important factor for the return and the retention of migrants in Latvia is related to sensemaking - the meaning and sense people attribute to life in Latvia. The data in this study supports the data from Zača et al (2018) on youth return migrants - life in Latvia is seen as an opportunity to contribute to the development of the homeland (Zača, Hazans, \& Bela, 2018). Interviews illuminate in an in-depth manner that the sense of belonging is important - life elsewhere denotes one as just a guest of whose difference they are reminded of in different ways. In several interviews, return migrants highlight that one feels needed in Latvia, that one can make a significant contribution to the development of country and the wellbeing of society. Some also see it as their mission: to challenge and change the system (especially in medicine), to improve something, to transfer experiences, as well as values and attitudes, acquired abroad, such as self-respect, tolerance, kindness, and positive attitudes towards life and one another. 


\section{Conclusions}

In Latvia, like for other countries with high emigration rates, return migration can play an important role for economic competitiveness and development if policy is implemented accordingly. Our findings confirm the findings of previous studies - contribution of return migrants is linked to both the transfer of knowledge and skills, and to the transfer of values, ideas, practices, identity and social capital (Levitt \& Lamba-Nieves, 2011; Kuznetsov, 2013). Regarding migration trends, return migrants boost the number of inhabitants in Riga and Pierīga, yet in Latgale and other regions return migration is not able to compensate for the loss of population. Potential for return migration to revitalize the regions is questionable as the majority of highly skilled migrants stay in Riga and Pierīga. The study illuminates the barriers for return to towns, villages and countryside - it is limited job opportunities, lower salaries, reliance on personal contacts, devaluation of experience gained abroad, limited access to affordable quality housing, as well as limited scope of services and leisure activities are all more pronounced when compared to Riga and Pierīga. The facilitating factors that contribute to choosing towns, villages or countryside as places of residence after return are lower competition, stronger place attachment, high neighbourhood quality, a family friendly environment, slower life pace, opportunities to develop one's own business or practice sustainable way of life. However, at present moment the emotional and lifestyle factors seem to be of greater importance when one chooses to return to a town, village or countryside.

An analysis of migration trends and return migrants experiences allows to formulate some recommendations for policy makers. In order to attract a higher share of return migrants, including high skilled return migrants, to settlements outside of Riga and Pierīga, the income gap between regions should be reduced, and the availability of diverse and quality services in regions should be promoted. The results clearly show that return migrants' decision of where to live after returning is not just based on the availability of a good job, but on a variety of factors. Namely, these are access to education, hospitals, culture, entertainment, housing and infrastructure etc. Support for the diversification of business in regions is important, so that specialists with different skills and qualifications would be able to find a job better suited to their skills. The increase in the prevalence of remote work following the recent pandemic could contribute to the choice of residence outside the capital and Pierīga. Affordable quality housing also is one of key factors to attract young specialists. The benefits of small towns and rural life must be strongly promoted, and municipalities should enhance targeted communication with their emigrants abroad. 
Mierina \& Bela, 2021. Can Return Migration Revitalise Latvia's Regions? Facilitators and Barriers to Human Capital Gains

\section{Acknowledgements}

This study is developed with the support of National Research Programme «Towards sustainable development and inclusive society in Latvia: response to demographic and migration challenges» (Nr. VPP-IZM-2018/1-0015). The authors thank the students of master study programme "Sociology" at University of Latvia for their contribution in conducting 15 semi-structured interviews during the course "Migration and Integration" (2019).

\section{References}

Atoyan, R.V., Christiansen, L.E., Dizioli, A., Ebeke, C.H., Ilahi, N., Ilyina, A., Mehrez, G., Qu, H., Raei, F., Rhee, A.P. \& Zakharova, D.V. (2016). Emigration and its economic impact on Eastern Europe. IMF Staff discussion note SDN 16/07. Retrieved from https://www.imf.org/external/pubs/ft/sdn/2016/sdn1607.pdf

Barro, R., \& Sala-i-Martin, X. (2004). Economic growth. Cambridge: The MIT Press. Retrieved from https://library.diplomatic.ac/wp-content/uploads/2020/02/epdf.pub_economicgrowth.pdf

Docquier, F., Ozden, Ç., \& Peri, G. (2014). The labour market effects of immigration and emigration in OECD countries. The Economic Journal, 124 (579), 1106-1145. DOI: https://doi.org/10.1111/ecoj.12077

Glorius, B. (2019). Transnational Social Capital in Migration: The Example of Student Migration from Bulgaria to Germany. Social Inclusion, 7(4): .242-232 DOI: 10.17645/si.v7i4.2390

Kurekova, L. M. \& Žilinčíková, Z. (2018). What is the value of foreign work experience for young return migrants? International Journal of Manpower, 39 (1):71-92. Retrieved from https://datubazes.lanet.lv:5879/insight/content/doi/10.1108/IJM-04-2016-0091/full/html

Haque, N. U., \& Kim, S. J. (1995). "Human capital flight”: Impact of migration on income and growth. Staff Papers, 42(3), 577-607. DOI: https://doi.org/10.2307/3867533

Hazans, M. (2015a). Smadzenu aizplūde no Latvijas 21. gadsimtā. No I. Mierina (sast.) Latvijas emigrantu kopienas: cerību diaspora (85-92). Rīga: LU Filozofijas un socioloǵijas institūts.

Hazans, M. (2015b). Emigrācija no Latvijas 21. gadsimtā reǵionu, pilsētu un novadu griezumā. No I. Mierina (sast.) Latvijas emigrantu kopienas: cerību diaspora (11-25). Rīga: LU Filozofijas un socioloǵijas institūts.

Hazans, M. (2016). Atgriešanās Latvijā: remigrantu aptaujas rezultāti. Rīga: LU Diasporas un migrācijas pētījumu centrs. Retrieved from https://www.diaspora.lu.lv/fileadmin/ user_upload/lu_portal/projekti/diaspora/petijumi/Atgriesanas_Latvija__petijuma_zinojums.pdf

Hazans, M. (2020). Diasporas apjoma novērtējums. Rīga: LU Diasporas un migrācijas pētījumu centrs. Retrieved from https://www.diaspora.lu.lv/ fileadmin/user_upload/ lu_portal/projekti/diaspora/petijumi/Diasporas_apjoma_novertejums_-_Zinojums.pdf

Kaša, R., \& Mierina, I. (2019). The emigrant communities of Latvia: national identity, transnational belonging, and diaspora politics. Springer Nature.

Koroḷeva, I. (2020). Piederības izjūta un atgriešanās plāni: kas mainījies Latvijas diasporā? Akadēmiskā dzīve, 56(1), 28-45. DOI: http://doi.org/10.22364/adz.56.01 
Krēsliņš, K., Miglavs, A \& Spuriņš, U. (2015). Depopulation and regional development. Rīga: CERTUS. Retrieved from: http://certusdomnica.lv/en/agenda/depopulation-andregional-development/

Kureková, L. M., \& Žilinčíková, Z. (2018). What is the value of foreign work experience for young return migrants?. International Journal of Manpower, 39 (1), 71-92. DOI: https://doi.org/10.1108/IJM-04-2016-0091

Kuznetsov, Y. (ed.) (2013). How Can Talent Abroad Induce Development at Home? Towards a Pragmatic Diaspora Agenda. Washington DC: Migration Policy Institute.

Levitt, P., \& Lamba-Nieves, D. (2011). Social remittances revisited. Journal of Ethnic and Migration Studies, 37(1), 1-22. DOI: https://doi.org/10.1080/1369183X.2011.521361

McCann, P. (2013). Modern urban and regional economics. Oxford: Oxford University Press

Mieriņa, I. (2015). Prom no mājām, tuvāk sirdij? Kā ilgstoša atrašanās ārpus Latvijas ietekmē politiskās attieksmes un politisko procesu vērtējumu Latvijā. Akadēmiskā Dż̄̄ve, 51(1), 24-38. Retrieved from https://www.lu.lv/par-mums/lu-mediji/zurnali/akademiskadzive/arhivs/51numurs/

Mieriņa, I., Ose, L., Kaprāns, M. \& Lāce, A. (2017). Vienojošas nacionālās identitātes un Latvijas kultūrtelpas nostiprināšana. Priekšlikumi sabiedrības integrācijas politikas plānam 2019.-2025. gadam. Rīga: LU Diasporas un migrācijas pētījumu centrs.

Ministry of Economics. (2019). Latvijas ekonomika attīstības pārskats. Retrieved from: https://www.em.gov.lv/files/tautsaimniecibas_attistiba/leap/leap2019.pdf

Rasnača L. \& Bela, B. (2015). Social dimension of the measurement for regional development. Research for rural development 2015. Annual 21st International Scientific Conference Proceedings, 2, 126.-132. Retrieved from http://www2.llu.lv/research_conf/ Proceedings/21st_volume2.pdf

Rutkovska, A. (2018). Kāa attīstās Latvijas reǵioni. Retrieved from https://www.makro ekonomika.lv/ka-attistas-latvijas-regioni

Saeima of the Republic of Latvia. (2010). Sustainable Development Strategy of Latvia until 2030. Retrieved from: http://www.latvija2030.lv/upload/latvija2030_saeima.pdfLR Saeima.

Suciu, M. C., \& Florea, C. A. (2017). An empirical study on the migration among young skilled and creative people. Amfiteatru Economic Journal, 19 (46), 727-741. Retrieved from https://www.econstor.eu/handle/10419/169101

Suciu, M. C. \& Florea, C. A. (2017). An Empirical Study on the Migration Among Young Skilled and Creative People. Amfiteatru Economic, 19 (46), 727-741. Retrieved from https://www.researchgate.net/publication/318860022_An_Empirical_Study_on_the_Mi gration_Among_Young_Skilled_and_Creative_People

Staniscia, B., Deravignone, L., \& Gonzalez-Martin, B. et al. (2019). Youth mobility and the development of human capital: is there a Southern European model? Journal of Ethnic and Migration Studies. Ahead-of-print, 1-17. DOI: 10.1080/1369183X.2019.1679417

Šķiņ̧̧is, P. Vilka, I., Cimdiņš, R. \& Ušča, M. (2015). Rīcībspējas novērtēšana teritorijās. Zobena, A.\& İjabs, I. (sast.). Jaunas pieejas sociālās attīstības mērī̌sanā: cilvēki, teritorijas, pašvaldības (281.-306). Rīga: LU Sociālo un politisko pētījumu institūts.

VARAM. (2013) Reǵionālās politikas pamatnostādnes 2013.-2019. gadam. Ministru kabineta 2013.gada 29.oktobra rīkojums Nr. 496. Rīga: VARAM.

VRAA. (2020). Aprēḳināti 2019.gada teritorijas attīstības līmeņa indeksi. 31.07.2020. Retrieved from https://www.vraa.gov.lv/lv/jaunums/aprekinati-2019gada-teritorijasattistibas-limena-indeksi 
Mierina \& Bela, 2021. Can Return Migration Revitalise Latvia's Regions? Facilitators and Barriers to Human Capital Gains

Wallerstein, I. (1990). World-Systems Analysis: The Second Phase. Review (Fernand Braudel Center), 13(2), 287-293. Retrieved from http://www.jstor.org/stable/40241154

Zača, E., Hazans, M., Bela, B. (2018). Atgriešanās apstāklı un nosacījumi. Rīga: LU SZF SPPI Diasporas un migrācijas pētījumu centrs. Pieejams https://www.diaspora.lu.lv/fileadmin/ user_upload/LU.LV/Apaksvietnes/Fakultates/www.szf.lu.lv/Atgriesanas_apstakli_DMP C_05-04-labots_FIN-maketam__1_.pdf 